Volume and Issues Obtainable at Center for Sustainability Research and Consultancy

Sustainable Business and Society in Emerging Economies

ISSN: 2708-2172 \& (E): 2708-2504

Volume 3: Issue 4 December 2021

Journal homepage: www.publishing.globalcsrc.org/sbsee

\title{
Impact of Status Consumption on Buying of Fashion Products and its Behavioral Outcomes in Context of Young Female Consumers
}

Zara Hayat, Bahauddin Zakariya University, Multan, Pakistan

*Hayat Muhammad Awan, Institute of Southern Punjab, Multan, Pakistan

Sahar Hayat, NFC Institute of Engineering and Technology, Multan, Pakistan

*Corresponding Author's Email: prorector@ isp.edu.pk

\begin{tabular}{l}
\hline ARTICLE DETAILS \\
\hline History \\
Revised format: Nov 2021 \\
Available Online: Dec 2021 \\
\hline Keywords \\
Status consumption, fashion \\
fan ship, fashion conscious, \\
young female students \\
\hline JEL Classification \\
M1, M2
\end{tabular}

\begin{abstract}
Purpose: The purpose of doing this research study is to explore the three important research objectives which explore the impact of fashion related behavioral outcomes of female university students, residing in Pakistan. The concept of this research study arises due to lack of academic inquiry about the influence of materialism on FC and SC particularly among female university students of Pakistan.

Methodology: Building framework on these bases frame work is developed which shows materialism shows positive relationship with SC and FC. Reason is that Islam is most modernized religion and allows its followers to adopt all the new trends (of fashion or from any field).
\end{abstract}

Findings: The findings suggests that the sample under study have religious thoughts, they full fills all the orders of Allah, say their prayers daily, but they also seem fashionable not vulgar. Everything that seems vulgar or comes in the category of extravagance is not allowed in Islam.

Finding of this paper support previous work and tell that status and materially driven female students need to attain social attention so they use fashionable products to enhance their self-image. In similar concern, the relationship between other variables like fashion consciousness and its effect on selfimage.

Implications: In Pakistan, fashion consciousness is increasing rapidly. This study will be helpful for brands and policy makers to better under consumer need and serve them accordingly.

\section{OPEN ACCESS}

(C) 2021 The authors, under a Creative Commons AttributionNonCommercial- 4.0

Recommended citation: Hayat, Z., Awan, H. M. and Hayat, S. (2021). Impact of Status Consumption on Buying of Fashion Products and its Behavioral Outcomes in Context of Young Female Consumers. Sustainable Business and Society in Emerging Economies, 3 (4), 629-640. 


\section{Introduction}

In today`s world, Fashion become a extensively and most renowned fact. Companies are introducing fashion trends for the consumers and familiarizing new and latest styles to fulfill their persona on daily basis. Sense of fashion gives birth to Fashion consciousness (Tigert, Ring \& King, 1976) which is response of individual towards novel fashion styles. For representing social status, consumer gets involved in status consumption activities, why and how they do so, this is an important query to explore (Vigneron \& Johnson, 2004). In Pakistan, Fashion consciousness is increasing rapidly. The consumer based research ignores this issue regardless of the dramatic variations in behaviors of female fashion and status consumption over the past 15 years in the developing economies. Studies on this topic have been sparse in Islamic countries, in contrast to Western countries, where they have been extensively held (e.g. Eastman and Eastman, 2011; Kastanakis and Balabanis, 2012) Consequently, it becomes vital to investigate the particularity of Islam and its influence on this emerging marketplace for consumers (Al-Mutawa, 2013). It's an Islamic perspective on Muslim customers that Al-Mutawa (2013) has taken into consideration. Muslims females are backed by their religious beliefs, they do what Islam allow them to do, same is the case for their decision for buying fashion products. Strategic motivating and decisions making factors for buying fashion brands; beauty and esthetics for females as they are the major buyers of luxury and fashion market. A key factor behind this study suggests the buying behavior of fashion conscious female university students which suggests that they are fashion conscious and involve in status consumption activities to differentiate their self -image from others. Most of the fashion-related researches have been conducted in developed countries but in developing countries like in Pakistan, this area is untouched.

This study work aims to expand our understanding of the relationship by investigating ideas about female consumers' fashion consciousness and status consumption. On the basis of the foregoing, this study examines how a moderating variable such as materialism (Goldsmith, Flynn, \& Eastman, 1996; O'Cass, 2001a, 2001b) influences the association between status consumption and fashion consciousness, both of which contribute to self-image enhancement among female consumers in Pakistan.

Founded on the abovementioned literature, the research questions for this study are as follows:

1) What is the effect of fashion consciousness on behavioral outcomes of consumers?

2) What is the mediating role of fashion consciousness on fashion oriented behaviors and its outcomes?

3) What is the moderating role of materialism on fashion conscious behaviors of consumers?

We develop theory in section 2 based on these questions and the methodology is discussed in the section3. Whereas section 4 deals with the data analysis and section 5 builds the discussion and the implications of the results.

\section{Theory Development}

\section{Fashion Consciousness and Status Consumption}

Fashion consciousness and status consumption are deeply discussed by Goldsmith et al. (1996); O'Cass (2001a, 2001b); Eastman et al. (1999); O'Cass and Frost (2002); Dodd et al.(2000) andO'Cass, (2004). They defined it as the stimulator which endeavors a person to enhance their prestige and self-image in society with the help of noticeable consumption on products clearly symbolize their status. Status-seeking consumers are extremely fashion conscious and eagerly get knowledge about fashion brands (become fashion fan) which boost up their social status through the usage of brand status (Elliott, 1994; O'Cass and Frost, 2002; Vigneron and Johnson, 1999). Therefore we propose the conceptual framework given in fig. 1 and hypothesize as:

\section{H1: Status consumption has significant effect on fashion consciousness among consumers.}




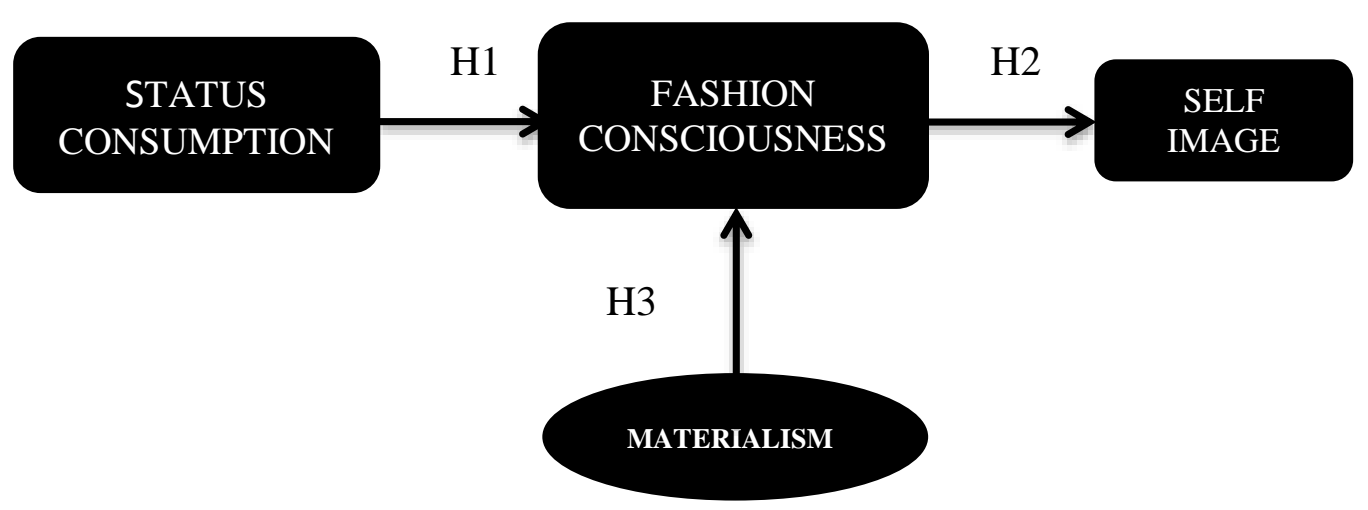

Figure 1.Proposed Conceptual Framework

\section{Fashion Consciousness, Status Consumption and Materialism}

Several studies have looked at the connections between materialism and various types of possession-related behavior (Belk 1984; Belk and Pollay 1985; Richins and Dawson 1992; Achenreiner, 1997 and $\mathrm{Gu}$ et al. 2005), materialism and consumption of social status (Fitzmaurice and Comegys 2006; Heaney et al. 2005; O'Cass 2001b and Watson 2003), and the concept of self-monitoring and materialism (Wat (Browne \& Kaldenberg; 1997).

Scholars discussed that materialism is positively correlated to status consumption. It is stated that people with more materialistic approach express greater attraction to maintain their status as compared to other non-materialistic people. However, the individual who has materialistic appeal will be able to generate status consumption from different antecedents as a result of his materialist orientation (Pentecost, 2009). A highly-materialistic group, while exploring the individual effect alone finds out that it exposes secondary reaction (through fashion consciousness) on status consumption, however the less materialistic people entails self- image as a supplementary reason for consuming status oriented products. Products plays more central role in the life of women as compared to men (Lertwannawit et al. 2011). Therefore materialism is presented as a moderator in this study on the basis of this literature review.

\section{H3: Materialism moderates the relationship between status consumption and fashion consciousness.}

\section{Resultant Behavioral Outcome of Fashion Consciousness}

Fashion consciousness usually measures a person's degree of involvement towards fashion and its fanship; their cognitive and behavioral reason was discussed by Bakewell et al., (2006) and Goldsmith and Stith (1992). Goldsmith (1992) demonstrates the prominence of self-image on consumer behavior. The discussion of self-concept was initiated by Levy (1959) who argued that the consumer is fashion oriented and their behavior is significantly affected by the symbolic representation by products. Consumers repeatedly purchase brands or products which boost up their genuine or idyllic self-image (Malhotra, 1988; Onkvisit and Shaw, 1987; Sirgy, 1982). Self-image basically related to fashion behavior of a customer as most significant component of fashion is clothing which is display of self (Davis, 1985; Evans, 1989; Lurie, 1981).Consumers wear fashion clothes to show others their personality and communal status (Lurie, 1981).Hence the following hypotheses are proposed. 


\section{H2: Fashion consciousness has a significant effect on self-image among consumers. H4: Fashion consciousness mediates the relationship between status consumption \& self- image.}

\section{Methodology \\ Research Design}

Underlying research is a chunk of a superior study on behavior of female students focusing on fashion and its resultant behaviors. A sample of university females were chosen for Responses to test the hypotheses, because they are more inclined towards fashion, fashion clothing and its related products. For this concern, Questionnaires were firstly designed and administered then distributed to collect data from five big cities of Pakistan i.e., Karachi, Lahore, Islamabad, Faisalabad and Multan. This data collection approach helps to confirm the participation of students from different areas of Pakistan.

Self-administered questionnaires having 7 points likert scale (starting from strongly disagree to strongly agree) was developed to test and analyze the proposed hypotheses. Questionnaire technique for data gathering for fashion consciousness was formerly used by several authors (e.g., O'Cass et al., 2008; Voss, et al., 2003). Population selected for proposed frame work was female university students from five big cities of Pakistan. Female students from universities were both from government as well as from private universities in selected cities. They lie in the age group from 18-35. For Students, doing shopping is a source of joy and happiness; also they get substantial knowledge about the market place and fashionable products (Goldsmith et al., 2012; Schiffman \& Kanuk, 2006).

\section{Sample Size}

The sample size for this research comprises of data from five hundred(500) female university students from government and private universities in the ratio of $70 \%$ (i.e., 350 questionnaires) data from government universities and 30\% (i.e., 150 questionnaires) from private universities. Questionnaire got filled by students of different departments and disciplines of study like, engineering, business administration, fine arts, Islamic studies, linguistics etc.

\section{Sample Characteristic}

The surveys (questionnaires) that got returned after completion, 469out of 500 questionnaires were sort out to be work able, representing a response rate of 93.8 in each hundred. In terms of age distribution it was specified as follow: 19.0 percent were 15-20 years old, 42.8 Percent respondents were of age 21 to 25 years, 25.4 percent came in the age criteria of 26 t0 30 years, 5.1 percent were of age 31 and 35 years, 1.5 percent of female university respondents lies in the age group of 36 to 50 years.

\section{Measures}

To measure status consumption, scales were adapted from the work of Eastman, Goldsmith, and Flynn (1999). Scales of Materialism were adapted from the study of Richins\& Dawson (1992). Fashion consciousness was measured by using scales from the work of Shim and Gehrt (1996). While scales of self- image were adapted from the study of Rosenberg (1965).

\section{Brand Stimuli}

A brand is actually the amalgamation of its name and image, when the consumer believes that a brand closely synchronizes to their own requirements (or desires) because of its exclusivity, it is consider as a popular brand (De Chernatony\& McDonald 1998). Five brands were chosen as impulses for the purpose of this study, their visually attractive logos were shown to respondents in first stage of brand recognition degree of its familiarity. The choice of brand as a stimulus relies on two standards. Firstly, the degree to which these brands were extensively available and 
easily accessible throughout the five selected big cities of Pakistan. Secondly, the extent to which the target respondents were aware with these brands.

The five brands that had the highest familiarity and purchase frequency, scores high in careful selection and analysis. Names of prestigious and famous brands in Pakistan that were sort out after screenings i.e. Calvin Klein, Chanel, Gucci, Christian Dior and Burberry. In Pakistan, Calvin Klein and Christian Dior are to be the brands for which customers are willing to pay premium priced, which can be comparatively higher than the other selected brands for this study. For example, in the eyes of Movius (2006), Calvin Klein seemed as a jeans brand which leads in American. The other selected three brands for study (i.e. Gucci, Burberry and Chanel) are relatively lower pricing but are mass-marketed brands with significantly stronger market penetration due to its various products.

\section{Data Analysis \\ Principal Factor Analysis}

SPSS software and IBM AMOS version 21 is utilized on whole data. The principal factor analysis examined the attributes of variables. Confirmatory analysis confirms that the remaining items after removing less relevant items. Regression analysis was executed using structured equation modeling (SEM) for testing of constructs. Model fit was also pragmatic on structure equation modeling. The mediating effect of variables was investigated through bootstrapping method. The moderating effect of two variables was examined in this study.

\section{Exploratory Factor Analysis}

To analyze data, conceptual framework to explore on status consumption, fashion consciousness, materialism. It is desirable to apply the confirmatory factor structure on independent variables, thereby reduce the chance of error in analysis the values of proposed model (Chin \& Todd, 1995).

Principal factor analysis was applied along with varimax rotation and Kaiser Normalization which was useful to review all values, where employing a factor weight of 0.50 as a minimum cut-off value and those values of constructs' were selected for analysis which were 0.50 or more then it, the values below 0.50 were considered to be the items which were problematic for further calculations and they got removed. Initially the four constructs were consist of 31 items bot the EFA reduced them to 19 items.

\section{Confirmatory Factor Analysis}

CFA is applied on items which are confirmed as relevant after exploratory analysis. The Cronbachs' coefficient is used for Reliability assessment, whose value is $90.2 \%$ on 19 items extracted from EFA and confirmed by CFA, which is satisfactory percentage for that exploratory research(Nunnally \&Bernstein, 1994). The first construct / scale relates to status consumption has Cronbach`svalue 0.726,;materialism Cronbach`s value which is 0.824 ; and last construct has the Cronbach`s value 0.857 . The results are Mention in table 2 . This study utilizes analysis techniques like chi-square, Relative chi-square, goodness of fit index (GFI), Root Mean Square Residual (RMS), to evaluate the appropriateness of research model, hence proving the finding of Arbuckle (1999) \&Vigoda (2000). The chi square has value 2.03 with degree of freedom is 3 , it is accurate for significant level of 0.005 . Sensitivity of chi square increase when number of indicators increases. Chi square ratio as compared to degree of freedom must not surpass by 3 (Joreskog and Sorborn 1996). Keeping this point in mind, further analysis is performed and then examined. Further analysis presents excellent model fit, where GFI=.996, AGFI= .907, RMR=.057. These values are thought to be accurate according to the findings of Byne (1998); Hu and Bentler (1998). These values suggests that the suggested frame work is appropriate while consider it with goodness of fit test. 
Table 1: Confirmatory Factor Analysis along with Cronbach`s Alpha Values

\begin{tabular}{llllll}
\hline \multicolumn{5}{c}{ Rotated Component } & Matrix \\
\hline Items & Material & Fashion & Status & Cronbach`s & Internal \\
& ism & Consciousness & Consumption & alpha & consisten \\
& & & & cy
\end{tabular}

\section{STATUS CONSUMPTION}

I would buy a product just

because it has status.

I would pay more for a

product if it had status.

A product is more valuable to appeal.

\section{MATERIALISM}

Some of the most important

achievements in life include acquiring material possessions.

The things I own say a lot about how well I'm doing in life.

I like to own things that .760 impress people.

I like a lot of luxury in my life.

.760

My life would be better if I owned certain things I don't .709 have.

I had be happier if I could afford to buy more things.

\section{FASHION CONSCIOUSNESS}

I keep up-to-date with the changing (i.e. latest) fashions.

The latest fashionable, attractive styling is important

to me.

Good

I generally try to keep up to date with latest fashion.

\section{Correlation Analysis}

Pearson correlation analysis was applied and the results are listed in table II. These results show that there is maximum contribution towards fashion consciousness $(r=0.440, p=0.000)$ from the materialism $(\mathrm{r}=0.440, \mathrm{p}=0.000)$. Other highest value exist between Status Consumption and materialism $(\mathrm{r}=0.334, \mathrm{p}=0.000)$ and Status Consumption and fashion consciousness( $\mathrm{r}=$ $0.345, \mathrm{p}=0.000)$. Other variables have values less than the above mention relationship. 
Table: 2

\begin{tabular}{lllll}
\hline Variables & SC & MAT & FC & SI \\
\hline SC & 1 & & & \\
MAT & $.334^{* * *}$ & 1 & & \\
FC & $.345^{* *}$ & $.440^{* *}$ & 1 & 1 \\
SI & $.225^{* *}$ & $.242^{* *}$ & $.215^{* *}$ & \\
\hline
\end{tabular}

**Significance level $<0.05$

\section{Regression Analysis}

With the help of AMOS version 21, the analysis of linear regression is performed to explore out in order to investigate the consequences, also check the relationship between the variables, all those relationship among these variables which shows their dependency on each other, the table (IIII), demonstrates all these relationships in detail.

Table: 3

\begin{tabular}{|c|c|c|c|c|c|c|}
\hline Relationship & $\begin{array}{l}\text { Hypothesis } \\
\text { number }\end{array}$ & Estimate & S.E. & C.R. & $\begin{array}{l}\mathbf{P} \\
\text { value }\end{array}$ & Results \\
\hline $\begin{array}{l}\text { fashion } \\
\text { consciousness < ---- status consumption }\end{array}$ & $\mathrm{H} 1$ & 0.077 & 0.022 & 2.422 & 0.015 & Supported \\
\hline Self- image <----fashion consciousness & $\mathrm{H} 2$ & 0.231 & 0.042 & 5.470 & 0.000 & Supported \\
\hline
\end{tabular}

H1 is 'Status consumption has significant positive affect on fashion consciousness among consumers. 'The outcome of research proposes that there is highly significant relationship between status consumption and fashion consciousness $(\mathrm{p}=0.015)$ with the $\mathrm{p}$-value which is $<0.05$. So it fully supports the H1. This finding is in line with the previous findings of different authors like, Lertwannawit, Mandhachitara (2011); O'Cass,Lee and Siahtiri (2013). This finding implies that female university students of Pakistan are fashion conscious, so they like all status oriented products, because these products full fill their need of fashion, gives them social status among their peer. Following these lines, the study proves that female university students of Pakistan show direct and positive relationship of status consumption with fashion consciousness, so the fashion marketers in Pakistan are capturing the perceptual approach of female university students and portraying their brands in the same ways which are able to satisfy their need of fashion and status.

$\mathrm{H} 2$ is 'Fashion consciousness has a significant positive affect on self-image among consumers. 'This means that Fashion consciousness has highly significant association with self-image among consumers $(\mathrm{p}=0.000)$, also proved by value of $\mathrm{p}$, which is $<0.05$. Hence this hypothesis is fully supported. This relationship was previously discussed by Goldsmith et al., 1999; Kaiser, 1990; Morganosky and Vreeman, 1986 cited in O'Cass and Frost, 2002) in their different studies. The female university students have a virtuous sense of fashion, they are more fashion conscious and evenfor their favorite brand they are ready to pay a premium amount to which they thinks matches those figurative qualities that efficiently enhances their personality and corresponds their self-image effectively to their communal circle.

\section{Mediating Role of Fashion Consciousness}

Hayes (2009) outlines mediating analysis (direct \&indirect) by usage of SPSS. The superior method for testing mediation is to calculate its indirect and direct effects by applying M Plus and 
AMOS, also by using bootstrapping and testify there significance level. Further analysis was performed to consider and examine the role of fashion consciousness in relationship between fashion products acquiring behavior and its resultant outcome like self -image is reported through H4. These hypothesis represents mediating effect of fashion consciousness with other variables. Table V shows indirect effect for SC and SI is 0.009

Table: 4 - Mediating Effect (Direct \& Indirect) On Variables

\begin{tabular}{|c|c|c|c|c|c|c|c|c|}
\hline $\begin{array}{l}\text { Model } \\
\& \\
\text { Hypothesis } \\
\text { No. }\end{array}$ & \multicolumn{3}{|c|}{ Relationships } & Estimate & S.E. & C.R. & $\begin{array}{l}P \\
\text { value }\end{array}$ & $\begin{array}{l}\text { In } \\
\text { direct } \\
\text { effect }\end{array}$ \\
\hline \multirow[t]{3}{*}{$\begin{array}{l}\text { M1 } \\
(\mathrm{H} 4)\end{array}$} & Fashion Consciousness & $<---$ & $\begin{array}{l}\text { Status } \\
\text { consumption }\end{array}$ & 0.325 & 0.041 & 7.969 & 0.000 & \\
\hline & self-image & $<---$ & $\begin{array}{l}\text { Fashion } \\
\text { Consciousness }\end{array}$ & 0.107 & 0.032 & 3.294 & 0.000 & \\
\hline & self-image & $<---$ & $\begin{array}{l}\text { Status } \\
\text { consumption }\end{array}$ & 0.11 & 0.031 & 3.607 & 0.000 & 0.009 \\
\hline
\end{tabular}

**Significance level $<0.05$

The direct effect of mediation on other variables is considered deeply. The results in table IV shows both direct and indirect effects of mediation where indirect effect of relationship SI and SC has a $\mathrm{p}$ value $=0.009$, while its direct effect value has $\mathrm{p}$ value $=0.000$, which is significant. It proves the mediation effect of fashion consciousness between status consumption and self-image. Hence hypothesis $\mathrm{H} 3$ get proven by findings. These evaluations recommend that the special effects of status consumption allocates to self-image via fashion consciousness for example in a case if the degree of fashion consciousness increased in the mind of female university students than their concept of status consumption more probably enhance their loyalty towards branded products. Some deviations in the level of female university students fashion consciousness will be able to diverge the degree of status consumption on self-image. For instance, if female university students are satisfied with the fashion brands they love, and displeased with other nonloved fashion brands, formerly it will make differences in the extent of their fashion consciousness. In these state of affair the outcome of status consumption on self-image will correspondingly differ. Consequently it is constructive argument that female university students resultant behavioral outcome of fashion (which is here in this hypothesis represents self-image) and their concept of status consumption basically governed by their degree of fashion consciousness.

\section{Moderation Analysis}

Table VI shows the results of moderating analysis between status consumption and fashion consciousness moderated by materialism.

\begin{tabular}{|c|c|c|c|c|c|c|c|c|}
\hline \multicolumn{9}{|c|}{ Table: 5} \\
\hline Relation & & & Hypothesis & Estimate & S.E. & C.R. & $\mathbf{P}$ & Label \\
\hline $\begin{array}{l}\text { Fashion } \\
\text { consciousness }\end{array}$ & $<---$ & $\begin{array}{l}\text { Materialism } \\
{ }_{-} \mathrm{x}_{-} \quad \text { Status } \\
\text { Consumption }\end{array}$ & H3 & 0.41 & 0.039 & 10.512 & 0.000 & Supported \\
\hline
\end{tabular}

Materialism moderates the relationship between FC and SC with p-value 0.000.H3 is supported. Materialism positively moderates the relationship between status consumption and fashion consciousness. " It has standard estimate value is 0.41 . Results show that there is a significant effect of materialism acting as a moderator on status consumption and fashion consciousness. In this way hypothesis number $\mathrm{H} 3$ got proved. If female university student shows strong relationship with Materialism, then obviously she will show a stronger relationship among status consumption and fashion consciousness. 


\section{Discussion and Implications}

The chief purpose of doing this research study is to explore the three important research objectives which explore the impact of fashion related behavioral outcomes of female university students, residing in Pakistan. The concept of this research study arises due to lack of academic inquiry about the influence of materialism on FC and SC particularly among female university students of Pakistan. In the light of gap in literature, the current study try to examine the degree to which female university students materialistic believes, that make their buying behaviors. This study also tries to find out to what extent female university students are status conscious and in return how much they are fashion conscious and self -aware, for buying their favorite fashionable goods. Building framework on these bases frame work is developed which shows materialism shows positive relationship with SC and FC. Reason is that Islam is most modernized religion and allows its followers to adopt all the new trends (of fashion or from any field). The findings suggests that the sample under study have religious thoughts, they full fills all the orders of Allah, say their prayers daily, but they also seem fashionable not vulgar. Everything that seems vulgar or comes in the category of extravagance is not allowed in Islam.

This research paper extended work of O`Cass 2004;O`Cass and Choy 2008; Eastman et al., 1999; Lertwannawit, Mandhachitara 2011; O'Cass,Lee and Siahtiri (2013)about the positive association of status consumption with fashion consciousness. Finding of this paper support previous work and tell that status and materially driven female students need to attain social attention so they use fashionable products to enhance their self-image. In similar concern, the relationship between other variables like fashion consciousness and its effect on self-image. Phau and Leng (2008) illustrated that status consumption of on symbolic as well as superior status product also help in boosting one`s social recognition and self-image, it also satisfies their fashion needs. Hu (2009) illustrated the positive and direct relationship between self -image and fashion conscious individual. The results of the study demonstrate that the female consumers are auxiliary fashion conscious, having materialistic approach; they categorically got tangled in all fashion related activities like buying of their desired brand, for that reasons they adore fashion and feel crazy to know and then buy every new fashion. They put efforts to monitor every foot print of hottest fashion.

Same is the approach for defining fashion consciousness and its relationship with self-image among consumers. This finding was previously conferred by Goldsmith et al., (1999); Kaiser, (1990); Morganosky and Vreeman, (1986) cited in O'Cass and Frost, (2002) and got proved by this study. The universal myths about women purchase behavior (which proved to be true after this study), exposed the fact that women loves fashion, are status conscious and do shopping more than men. Even for acquiring their desired brand they are often seem to pay any amount (premium price), sometimes they take loan from to get specific branded product which are according to their self-image and gives them their desired status among peers. These dimensions got proved with the help of significant statistical data that was previously collected to explore all research questions.

\section{Limitations and Recommendations for Future Research}

There are also delimitations while conducting that research. Firstly, it is a geographical bounded researchi.e. The study covers only major universities with in five cities of Pakistan i.e., Karachi, Lahore, Islamabad, Faisalabad and Multan. Secondly, it is cross sectional research, but one can go for this to see the difference over time of such relationships. Also, for future research data should be collected using mix technique i.e., both qualitative and quantitative techniques to get more accurate results. For elaborating buying behavior of fashion products, same research will be performed on both genders as a comparative study. Females above age group of 35 will act differently when same research will performed on them. This happens due to family and societal restrictions and responsibility on them. 


\section{References}

Achenreiner, G.B. (1997). Materialistic values and susceptibility to influence in children. Advances in Consumer Research, 24:82-8.

Al-Mutawa, F.S. (2013). Consumer-generated representations: Muslim women reacting western luxury fashion brand meaning through consumption. Psychology and Marketing, 30 (3), 236-246.

Arbuckle, J. (1999).AMOS 4.0 User's Guide, Small Waters Corporation, Chicago, IL.

Bakewell, C., Mitchell, V.W. and Rothwell, M. (2006). UK Generation Y male fashion consciousness. Journal of Fashion Marketing and Management, 10 (2), 169-180.

Belk, R.W. In: Kinnear T, editor (1984). Three scales to measure constructs related to materialism: Reliability, validity and relationships to measures of happiness. Advances in Consumer Research Association for Consumer Research, 291-7. Provo, UT.

Belk, R.W., Pollay, R. (1985). Images of ourselves: The good life in twentieth century advertising. Journal of Consumer Research, 11, 887-97.

Browne, B. \&Kaldenberg, D. (1997). Conceptualizing self-monitoring: Links to materialism and product involvement. Journal of Consumer Marketing, 14(1),31-44.

Byrne, B. (1998). Structural equation modeling with LISREL, PRELIS, and SIMPLIS: Basic concepts, applications, and programming: Lawrence Erlbaum.

Chin, Wynne, \& Todd, Peter A. (1995). On the use, usefulness and ease of use of structural equation modeling in MIS research: A note of caution. MIS Quarterly, (June) 237-246.

Davis, F. (1985). Clothing and fashion as communication in Solomon, M.R (Ed.), The Psychology of Fashion, Lexington Books, Lexington, MA, pp. 15-27.

De Chernatony, L. \& McDonald, M. (1998) .Creating Powerful Brands. Oxford university press, Butterworth Heinemann, 2nd Edition.

Dodd, C. A., Clarke, I., Baron, S., \& Houston, V. (2000). Looking the part': identity, meaning and culture in clothing purchasing: theoretical considerations. Journal of Fashion Marketing and Management, 4(1), 41-48.

Eastman, J.K. and Eastman, K.L. (2011). Perceptions of status consumption and the economy. Journal of Business and Economics Research, 9 (7), 9-19.

Eastman, J.K., Goldsmith, R.E. and Flynn, L.R. (1999). Status consumption in consumerbehavior: scale development and validation. Journal of Marketing Theory and Practice, (7) 3, 41-52.

Elliot, R. and Yannopoulou, N. (2007). The nature of trust in brands: a psychological model. Journal of Marketing, 41(9), 988-998.

Evans, M. (1989).Consumer behaviour towards fashion. European Journal of Marketing, 23 (7), 7-16.

Fitzmaurice, J. \&Comegys, C. (2006). Materialism and social consumption. Journal of Marketing Theory and Practice, 14(4), 287-99.

Forney, J.C., Park, E.J., and Brandon, L. (2005). Effects of evaluative criteria on fashion brand extension. Journal of Fashion Marketing and Management, 9(2), 156-65.

Goldsmith, R.E., Flynn, L.R. \& Eastman, J.K. (1996). Status consumption and fashion behavior: An exploratory study. The Association of Marketing Theory and Practice: Association of Marketing Theory and Practice Proceedings. Hilton Head, SC, p. 309-16.

Goldsmith, R.E., and Stith, M.T. (1992). The social values of fashion innovators. Journal of Applied Business Research, 9 (1), 10-16.

Goldsmith, R. E., Moore, M. A., \&Beaudoin, P. (1999). Fashion innovativeness and self-concept: a replication. Journal of Product \& Brand Management, 8(1), 7-18.

Goldsmith, R.E., Flynn, L.R., and Kim, D. (2010). Status consumption and price sensitivity. Journal of Marketing Theory and Practice, 18(4), 323-38.

Gould, S.J., Stern, B.B. (1989). Gender schema and fashion consciousness. Psychology and Marketing, 6 (2), 129-145.

Gu, F.F., Hung, K. \&Tse, D.K. (2005). Determinants for consumption materialism among late 
adolescents in China. Advances in Consumer Research, 32,649-50.

Hayes, A.F. (2009), "Beyond Baron and Kenny: statistical mediation analysis in the new Millennium. Communication Monographs, 76 (4), 408-420.

Heaney, J.G., Goldsmith, R.E., Jusoh, W.J.W. (2005). Status consumption among Malaysian consumers exploring its relationships with materialism and attention-to-socialcomparison-information. Journal of International Consumer Marketing, 17(4),83-98.

Hu, X. (2009). Self-Concept, Acculturation, and Fashion Orientation.

Hu, L. and Bentler, P.M. (1998). Fit Indices In Covariance Structure Modeling: Sensitivity to Underparameterized Model Misspecification. Psychological methods, (3) 4, 424.

Jöreskog, K. and Sörbom, D. (1996), LISREL 8: User's Reference Guide. Chicago, IL: Scientific Software International Inc.

Kaiser, S. B. (1990). Fashion as popular culture: The postmodern self in the global fashion marketplace. The World and I, 5(7), 521-529.

Kastanakis, M.N., and Balabanis, G. (2012). Between the mass and the class: antecedents of the 'bandwagon' luxury consumption behavior. Journal of Business Research, 65 (10), 1399-1407.

Lertwannawit, A. \& Mandhachitara, R. (2011). Interpersonal effects on fashion Consciousness and Status Consumption Moderated by Materialism in Metropolitan men. Journal of Business Research, 65, 1408-1416.

Levy, S. J. (1959). Symbols for Sale.Harvard Business Review, 37 (July-August), pp: 117-24.

Lurie, A. (1981). The Language of Clothes, Random House, New York, NY.

Malhotra, N. K. (1988). Self-concept and product choice: an integrated perspective. Journal of Economic Psychology, 9, 1-28.

Morganosky, M.A. and Vreeman, A.L. (1986). The involvement concept: relationships to the apparel consumer", unpublished manuscript - cited in O'Cass, A. and Frost, H. (2002). Status brands: examining the effects of non-product-related brand associations on status and conspicuous consumption. Journal of Product \& Brand Management, (11) 2, 6788.

Movius, L. (2006). The world of Calvin Klein visits China. Women's Wear Daily, November9, p.9.

Nunnally, J. C. and Bernstein, I. H. (1994). Psychometric Theory, 3d ed. McGraw-Hill Inc.

O'Cass, A. (2001a). Consumer self-monitoring, materialism and involvement in fashion clothing. Australasian Marketing Journal, 9(1), 46-60.

O'Cass, A. (2001b). Exploring the relationship between self-monitoring, materialism and product involvement in fashion clothing. Asia Pacific Advances in Consumer Research, 4, 183-9.

O'Cass, A., \& Frost, H. (2002). Status brands: examining the effects of non-product-related brand associations on status and conspicuous consumption. Journal of Product \& Brand Management, 11(2), 67-86. http://dx.doi.org/10.1108/10610420210423455

O'Cass, A. (2004). Fashion clothing consumption: antecedents and consequences of fashion clothing involvement. European Journal of Marketing, 38 (7), 869-882.

O'Cass, A. and Choy, E. (2008).Studying Chinese generation Y consumers' involvement infashion clothing and perceived brand status. Journal of Product and Brand Management, (17) 5, 341-352.

O’Cass, A., Lee, W.J., Siahtiri, V. (2013). Can Islam and status consumption live together in the house of fashion clothing? Journal of Fashion Marketing and Management. (17) 4, 440-459.

Onkvisit, S. \& Shaw, I. (1987). Self-concept and image congruence: some research and managerial implications. Journal of Consumer Marketing, (4) 1, 13-23.

Pentecost, R.(2009). Assessing the Role of Passion as a Mediator of Consumer Intentions to attend a Motor Sports Event.

Phau, I., \&Leng, Y. S. (2008). Attitudes toward domestic and foreign luxury brand apparel: A 
Comparison between Status and Non-Status Seeking Teenagers. Journal of Fashion Marketing and Management, 12(1), 68-89.

Richins, M.L., Dawson, S. (1992). A consumer values orientation for materialism and its measurement: scale development and validation. Journal of Consumer Research,19, 303-316.

Rosenberg, M (1979), Conceiving the Self, New York: Basic Books.

Schiffman, L., \&Kanuk, L. (2006). Consumer Behavior .New York: Prentice-Hall. Ed. 9th.

Shaikh, A. S. (2013).Consumption Smoothing - An Islamic Economics Perspective. http://islamiceconomicsproject.wordpress.com/2013/05/06/consumption-smoothing-anislamic-economics-perspective/

Shim, S., \&Gehrt, K.C. (1996). Hispanic and Native American adolescents: An exploratory study of their approach to shopping. Journal of Retailing, 72(3), 307-24.

Sirgy, M.J., (1982). Self-concept in consumer behavior: a critical review. Journal of Consumer Research, 9 (3), 287-300.

Tigert, D. J., Ring, L. J., \& King, C. W. (1976). Fashion Involvement and Buying Behavior: A Methodological Study. Advances in Consumer Research, 3(1), 50-51.

Vieira, V.A., (2009). An extended theoretical model of fashion clothing involvement. Journal of Fashion Marketing and Management, 13(2),179-200.

Vigoda, E. (2000). Are You Being Served? The Responsiveness of Public Administration to Citizens Demands; an Empirical Examination In Israel. Public Administration, (78) 1, 65-191.

Vigneron, F. and Johnson, L.W. (2004). A review and a conceptual framework of prestigeseekingconsumer behavior. Academy of Marketing Science Review, 9(1),1-14.

Voss, K. E., Spangenberg, E. R., \&Grohmann, B. (2003). Measuring the hedonic and utilitarian dimensions of consumer attitude. Journal of Marketing Research, 40(3), 310-320.

Watson, J.J. (2003). The relationship of materialism to spending tendencies, saving, and debt. Journal of Economic Psychology, 24(6), 723-39.

Walsh, G., Mitchell, V.W., Hennig-Thurau, T. (2001). German consumer decision-making styles. Journal of Consumer Affairs, 35(1), 73-95.

Wells, W.D. \&Tigert, D.J. (1971). Activities, interests and opinions. Journal of Advertising Research, 11(4), 27-35. 